\title{
Neomarxismo e neopragmatismo no século XXI
}

\author{
Giovanni Semeraro*
}

Não veio à mente de nenhum desses filósofos procurar o nexo existente entre a filosofia alemã e a realidade alemã, o nexo entre sua crítica e seu próprio ambiente material.

K. Marx

\section{ProXimidADE E CONTRAPOSIÇÃO ENTRE FILOSOFIA DA PRÁXIS E PRAGMATISMO}

Em artigo recente, publicado pela revista Critica Marxista da Itália, Chiara Meta ${ }^{1}$ apresenta um estudo onde mostra diversas convergências entre a filosofia da práxis elaborada por Gramsci e o pragmatismo de alguns clássicos americanos, principalmente, William James e John Dewey. Ao lembrar que Gramsci considerava "Os princípios de psicologia" de W. James "o melhor manual de psicologia"2 indica que no Caderno 22 há alguns elementos (atos voluntários e involuntários, atividade muscular-nervosa, etc.) e o próprio conceito de "hábito" derivados do autor norte-americano.

Interessantes são, também, os pontos de contato que a autora procura colocar em evidência entre Gramsci e Dewey, particularmente no que se refere à questão pedagógica e à

* Giovanni Semeraro, Professor Adjunto de Filosofia de Educação na UFF, Coordenador do Núcleo de Estudose Pesquisas em Filosofia Política e Educação (NUFIPE), gsemeraro@globo.com.

1. Chiara Meta, "Filosofia della prassi e pragmatismo", Critica Marxista, n. 2/3, 2004, p. 41-53.

2. Antonio Gramsci, Lettere dal carcere, Edição de A. Santucci, Palermo, v. 2, Editora Sellerio, 1996, p. 249 (25 de março de 1929).

Marxismo e ciências humanas

cadernos cemarx, n-3-2006 51 
função democratizadora da escola. Ao mostrar que os dois se depararam com os processos de industrialização, de massificação, de um novo modo de produção e de conhecimento nas primeiras décadas do século XX, sugere que entre Democracia e Educação de Dewey e os Cadernos 12 e 22 de Gramsci há mais "passagens" subterrâneas do que se possa pensar.

Além de outras afinidades, como, por exemplo, uma certa convergência no entendimento da linguagem, o artigo chega a sugerir que, tal como na filosofia da práxis de Gramsci, os nexos filosofia-senso comum e filosofia-política caracterizam também o próprio pensamento do pragmatismo.

Pelo menos à primeira vista, certamente as sintonias entre filosofia da práxis e pragmatismo não são poucas. Além dos indicados no artigo de Meta, poderíamos assinalar aqui outros possíveis temas que nos ${ }^{3}$ (doravante citado pela letra $\mathrm{Q}$, do original italiano) prestar-se-iam para desdobramentos de um estudo paralelo mais amplo com o pragmatismo:

- a concepção de uma filosofia imanente $e^{4}$ e histórica ${ }^{5}$, destituída de metafísica ${ }^{6}$, de qualquer princípio de autoridade ou de vinculação religiosa que fomentem a submissão, a passividade, a alienação e a mistificação;

- o fim da filosofia tradicional essencialista, inatista ou transcendental ${ }^{7}$ e a sua construção experimental, pública e discursiva ${ }^{8}$;

- a oposição ao positivismo, a crítica do racionalismo e do idealismo9;

- a superação de dualismos e dicotomias que separam a matéria do espírito, o corpo da mente, o pensamento do ser, o sujeito do objeto, o homem da natureza, a historia da ciência ${ }^{10}$;

- o menosprezo pelas abstrações, pelo escolasticismo e os problemas inúteis;

- a ênfase na ação, nas práticas concretas, nos resultados verificáveis coletivamente ${ }^{11}$,

3. Antonio Gramsci, Quaderni del cárcere, Edição crítica de Valentino Gerratana, v. 4, Torino, Editora Einaudi, 1975.

4. Q 11, 1438, 528; Q. 16, 1226, 58.

5. Q 11, 1426, 522 .

6. Q 11, 1479, 552 .

7. Q 1, 119, 5132 .

8. Q 11, 1449, 534 .

9. Q $11,1403-58,51555$.

10. Q 4, 467, 5 41; Q 11, 1457, 537.

11. Q 10, 1330, 544 .

52 Neomarxismo e neopragmatismo no século XXI 
- a valorização da ciência e da experiência, do agir mais do que o contemplar ${ }^{12}$;

- a busca do consenso e o reconhecimento do senso comum ${ }^{13}$;

- o caráter histórico, social e superável do conhecimento, que deve ser continuamente verificado, entendido como fruto de construção e não de descoberta, vinculado a justificativas concretas, não a especulações e devaneios ${ }^{14}$;

- a construção de uma educação democrática, criativa, elaborada em conjunto, não hierárquica e autoritária ${ }^{15}$.

Estas e outras questões, juntamente com uma certa proximidade de linguagem, têm levado alguns autores a ignorar ou a secundarizar as diferenças e as contraposições entre filosofia da práxis e pragmatismo ${ }^{16}$.

$\mathrm{Na}$ verdade, embora poucas e sumárias, as referências que Gramsci dedica ao pragmatismo norte-americano (mas também italiano: Vailati, Prezzolini, Pareto, etc.) são de um autor que valoriza, sim, alguns aspectos, mas que acima de tudo ressalva a insuficiência e as contradições que o caracterizam. Se nos Cadernos, de um lado, anota: "Parece que eles [os pragmatistas] tenham percebido algumas questões reais e as tenham 'descrito' com uma certa exatidão, embora não tenham conseguido impostar os problemas e indicar a solução"17, por outro lado, não se deve esquecer que, para Gramsci, o pragmatismo norte-americano está marcado pelo "imediatismo", o "politicismo" e o "ideologismo", que o tornam menos "prático" do "filósofo italiano ou alemão"18. Na dinâmica do seu "pensamento em movimento"19, a pergunta que Gramsci se coloca no primeiro Caderno: "Pode o pensamento moderno difundir-se na América, superando o empirismo-pragmatismo, sem uma

12. Q 11, 1467, 545 .

13. Q 11, 1380, 512 .

14. Q 1, 114, 5123 .

15. Q 10, 1330, 544 .

16. Domenico Losurdo, no seu livro Antonio Gramsci dal liberalismo al "comunismo critico", Roma, Gamberetti, 1997, p. 122, faz referência a R. Mondolfo, II concetto di necessità nel materialismo storico (1912), que já no início do século passado procurava assimilar o marxismo ao pragmatismo, e depois também G. Pretti, II pragmatismo che cos'è? (1946) chegou a afirmar que "o pragmatismo apresenta semelhanças consideráveis com o marxismo, do qual parece ser até o irmão mais jovem".

17. Idem, ibidem.

18. Q 17, 1925, 522 .

19. Giorgio Baratta, As rosas e os cadernos, o pensamento dialógico de Gramsci, Rio de Janeiro, Editora DP\&A, 2004, p. 136 e segs.

Marxismo e ciências humanas

cadernos cemarx, n03-2006 53 
fase hegeliana?"20, encontra uma resposta no Caderno 17, onde afirma que, à diferença de "Hegel [que] pode ser considerado como o precursor teórico das revoluções liberais do séc. XIX, os pragmatistas, no máximo, têm ajudado a criar o movimento do Rotary Club ou a justificar todos os movimentos conservadores e reativos" ${ }^{\text {"1 }}$. Mais do que isso, na medida em que nos adentramos no estudo dos escritos de Gramsci para compreender o sentido que imprimiu à filosofia da práxis, perde-se de vista a aparente proximidade de alguns pontos com o pragmatismo, diante das fortes diferenças e das contraposições que emergem. Quando, depois, como tentaremos mostrar aqui, se compara a concepção de filosofia da práxis de Gramsci com o neopragmatismo de Rorty, a distância se torna ainda mais incomensurável e intransponível.

\section{A ESPECIFICIDADE DA FILOSOFIA DA PRÁXIS}

Deve-se logo observar que quando se fala em "filosofia da práxis" estamos nos referindo ao pensamento mais peculiar engendrado pelo marxismo. Gramsci deixa claro que os "fundadores da filosofia da práxis" são Marx, Engels e Lenin ${ }^{22}$ e, em continuidade com o pensamento por eles inaugurado, procura, principalmente nos Q 10 e 11, aprofundar e conferir novos desdobramentos à filosofia marxista.

Como se sabe, a locução "filosofia da práxis" nos Quaderni del Carcere vai gradativamente substituindo a expressão "materialismo histórico" ainda utilizada para designar o marxismo nas três series de "Anotações de filosofia" dos Q 4, 7 e 8 23. Com isso, Gramsci procura não apenas se subtrair à censura carcerária, mas, principalmente, visa contribuir para a consolidação e atualização da nova concepção de mundo, uma tarefa na verdade percebida por Labriola ${ }^{24}$, que havia já afirmado que "A filosofia da práxis é o coração do materialismo histórico"25.

20. Q 1, 97, 5105.

21. Q 17, 1926, 522.

22. Q 10, 1315, 541; Q 11, 1436, 5 27; Q 16, 1856, 59.

23. A. Tosel, "Il lessico della filosofia della prassi di Gramsci", Revista Marxismo Oggi, Milano, Teti Editore, 1996, vol. 1, p. 49-67. F. Frosini, “Filosofia della prassi”, In:F. Frosinie G. Liguori, Le parole di Gramsci perun lessico dei Quaderni del cárcere, Roma, Carocci Editore, 2004, p. 93-111.

24. Q 11, 1507, 570; Q. 16, 1855, 99.

25. A. Labriola, "Discorrendo di socialismo e di filosofia", in A. Labriola, Scrittifilosoficie politici. Edição F. Sbarberi, Torino, Ed. Einaudi, 1973, p. 702-3.

54 Neomarxismo e neopragmatismo no século XXI 
De modo que, ao dedicar-se a aprofundar e destacar os aspectos mais importantes da filosofia da práxis, a preocupação de Gramsci não se limita a re-dialetizar o pensamento de Marx desfigurado por interpretações marcadas pela metafísica do materialismo mecanicista (Buckarin, Plekanov, etc.) ou pelo (neo)idealismo especulativo (Croce, Gentile, Bergson, Sorel, etc.). Como resume Martelli ${ }^{26}$.

Em antítese ao "monismo" metafísico idealista (hipóstase do "Espírito") ou positivistamecanicista (hipóstase da "Matéria"), que de maneira diferente separavam abstratamente o homem da natureza, e também em oposição ao criacionismo gnosiológico subjetivista, Gramsci elabora uma concepção materialista, mas ao mesmo tempo histórica e dialética, da relação homem/natureza, cujo baricentro é constituído pelo conceito de práxis.

Com suas reflexões sobre a filosofia da práxis, de fato, Gramsci procura reconduzir o marxismo ao desenho originário das Teses sobre Feuerbach de Marx e à pontualização que Engels faz em Ludwig Feuerbach e a crítica da filosofia clássica alemã. Mas, acima de tudo, para Gramsci aponta Frosini , "o problema da filosofia da práxis, é, ao mesmo tempo, o problema da filosofia depois de Marx, ou seja, do seu estatuto no nosso tempo"27. Por isso, além do resgate do pensamento originário de Marx, Gramsci procura destacar a especificidade, a originalidade e a maior consistência da filosofia da práxis em relação às outras filosofias. Preocupa-se, então, em colocar em evidência a autonomia, o pensamento novo e independente $e^{28}$ de um "marxismo [...] que contém em si todos os elementos fundamentais [...] de uma concepção global de mundo [...]"29, que "renova completamente a maneira de entender a filosofia" 30.

Para esta temática, remetemos a outros estudos: Kosik ${ }^{31}$; Losurdo ${ }^{32}$; Semeraro ${ }^{33}$. Nestas páginas nos limitamos a dizer, sinteticamente, que para Gramsci filosofia da práxis é a atividade teórico-política e histórico-social dos grupos "subalternos" que procuram desenvolver uma visão

26. M. Martelli, Gramsci filosofo della política, Milano, Ed. Unicopli, 1996, p. 41.

27. F. Frosini., "Filosofia della prassi”, cit., p. 16.

28. Q 4, 424, 53.

29. Q 4, 435, 514 .

30. Q 4, 433, 511 .

31. K. Kosik, “Gramsci e la filosofia della prassi”. In: E. Garin et al, (1969) Gramscie la cultura contemporanea. Atti del convegno internazionale di studi gramsciani, Roma, Editora Riuniti, 1969, p. 45-50.

32. Domenico Losurdo, "Gramsci, Gentile, Marx e le filosofie della prassi". In: P. Rossi. et al, (1990) Gramsci e il marxismo contemporaneo. Atti del convegno internazionale di studi gramsciani, Roma, Editora Riuniti, 1990, p. 90-114.

33. Giovanni Semeraro, Gramscie a sociedade civil, 2ª ed., Petrópolis, Ed. Vozes, 2000, p. 101-113.

Marxismo e ciências humanas

cadernos cemarx, $\left.\mathrm{n}^{0} \mathbf{3}-2006\right) 55$ 
global de mundo e um programa preciso de ação dentro do contexto em que vivem, com os meios que têm à disposição, visando construir um projeto hegemônico alternativo de sociedade. Martelli caracteriza a abrangência da filosofia da práxis em três aspectos inseparáveis: técnicoprodutiva; científico-experimental; histórico-política ${ }^{34}$. Aqui, acrescentaríamos apenas que:

- é práxis técnico-produtiva, porque faz do trabalho a "célula 'histórica' elementar"35, na formação de si mesmos, na mediação ativa que nós temos com a natureza e com os outros homens ${ }^{36}$;

- é práxis científico-experimental, porque atividade pública de reflexão e pesquisa em vista da construção de um conhecimento e de uma ciência voltados para a humanização do mundo e a expansão da democracia. Para Gramsci, de fato, "o cientista-experimentador é um trabalhador, não um puro pensador, e o seu pensamento é continuamente controlado pela prática e vice-versa, até se formar a unidade perfeita de teoria e prática"37;

- é práxis histórico-política, enquanto atividade que opera a mediação entre "vontade humana (superestrutura) e a estrutura econômica", entre "o Estado e a sociedade civil"38, entre histórias locais e o contexto global dos grupos subalternos, que, ao buscar a libertação, criam um novo modo de agir e de pensar, uma nova visão de mundo, uma filosofia que lança as bases para uma nova civilização.

Assim, para Gramsci, o homem não entra em relação com os outros e o mundo simplesmente pelo fato de ser ele mesmo natureza, mas ativamente, por meio do trabalho, da técnica, da filosofia e da política ${ }^{39}$. Daí porque, além de superar a naturalização do mundo, a cultura de subalternos, o imediatismo e o pragmatismo que afeta o agir das classes trabalhadoras, Gramsci se dedica principalmente a despertar neles a capacidade política que possa levá-los ao autogoverno e à direção de uma nova civilização.

Não há dúvida de que em Gramsci a filosofia da práxis é entendida como uma construção própria das classes subalternas, que se organizam, junto com seus intelectuais, para suplantar e superar a visão restrita e desumanizadora das classes elitizadas. Partindo das contradições ${ }^{40}$ do mundo dirigido e mantido por estes, a filosofia é da

34. M. Martelli, Gramsci filosofo della política, cit., p. 42.

35. Q 4, 473, 547.

36. Q 11, 1449, 534 .

37. Idem.

38. Q 7, 868, 518.

39. Q 10, 1345, 554 .

40. Q 11, 1487, 562.

56 Neomarxismo e neopragmatismo no século XXI 
práxis porque os subalternos, com suas práticas políticas, econômicas e culturais, conseguem elaborar uma proposta alternativa, universal e socializadora de mundo, superior à ordem existente, atribuindo-se a tarefa histórica de construir coletivamente, de baixo, uma nova, "total, integral civilização"41.

Para Gramsci, só assim os subjugados podem chegar à liberdade, à sua própria identidade e hegemonia. E a conquista desta "unidade na diversidade" acontece no processo político, por meio de uma "luta de hegemonias" 42 não procurando intelectualisticamente ${ }^{43}$ ou intimisticamente, dentro de si, o conhecimento, os valores e "as razões de vida" 44 . Pela filosofia da práxis, na verdade, o homem é visto como "conjunto das relações sociais" 4 , de relações não vagas e abstratas, mas dialeticamente concretas, consideradas dentro de precisas condições de trabalho, de um modo de produção material e simbólico, de divisões de classe, de distribuição da riqueza e do poder no mundo que nos engloba.

Como em Marx não se pode separar o pensar do agir, o mundo material da esfera das idéias, também em Gramsci há uma homologia entre a formação da vontade do indivíduo e a construção de um projeto coletivo de sociedade. Depois de Marx, de fato, chegaram ao fim as concepções de filosofias separadas, especulativa e ideologicamente manipuladas pelas classes dominantes, e inicia-se uma outra fase da humanidade, capaz de vincular organicamente o pensamento à economia e à política, uma vez que a realidade não pode ser pensada e entendida dualística e fragmentariamente. Para Gramsci, "separada da teoria da história e da política, a filosofia acaba se tornando metafísica; por isso, a grande conquista na história do pensamento moderno, operada pela filosofia da práxis, é exatamente a historicização concreta da filosofia e a sua identificação com a história"46. Daí porque: "a filosofia deve tornar-se política para ser verdadeira" 47

A crítica ideológica da filosofia significa, na prática, a reivindicação da sua ligação com a realidade concreta e histórica. Por isso Gramsci, enfatiza a estreita ligação entre

41. Q 11, 1434, 527.

42. Q 10, 1385, 512 .

43. Q $1,3355,543$.

44. Antonio Gramsci, Lettere del cárcere, cit., p. 421 (18 de maio de 1931).

45. Q 10, 1337, 548.

46. Q 11, 1426, 522 .

47. Q 11, 1472, 549.

Marxismo e ciências humanas

cadernos cemarx, nº 3- $2006 \quad 57$ 
filosofia, economia e política, e chega a afirmar que a filosofia da práxis "é uma filosofia que é também uma política e uma política que é também uma filosofia"48, e que "a reforma econômica é exatamente o modo concreto através do qual se apresenta toda a reforma intelectual e moral" 49 .

A ligação inseparável entre "filosofia, política e economia" 50 faz com que a filosofia não se dissolva na abstração ou no intimismo, a política não se torne um cego agir imediatista e pontual, a economia não seja vista como um poder separado, uma fatalidade incontrolável que incumbe sobre os destinos do mundo. Tanto a filosofia como a política e a economia, entrelaçadas, para Gramsci, formam indivíduos, conscientes de sua subjetividade social, fincados no terreno concreto da história e das suas contradições ${ }^{51} \mathrm{com}$ as quais precisa aprender a interagir para compreender seus mecanismos de poder e se organizar para operar transformações: "O filósofo, de fato, é e não pode não ser o político, quer dizer, o homem ativo que modifica o ambiente, entendido este como o conjunto das relações das quais cada um entra a fazer parte" 52 .

Assim, com uma diferença de acento em relação a Marx - que enfatiza mais os processos materiais e econômicos -, Gramsci evidencia que a formação da subjetividade política dos grupos subalternos não é dada automaticamente, de maneira direta, pela própria condição social ou pela simples inserção no processo de produção material, mas ocorre no processo de construção da hegemonia, por meio de um difícil e complexo trabalho político-cultural capaz de superar a fragmentação, a inércia e a submissão.

Não é por acaso que em Gramsci, é a ideologia o foco maior da sua atenção. "Para Gramsci, o coração da hegemonia sociopolítica de uma classe dirigente ou de uma classe revolucionária é a capacidade de produzir, ao lado da riqueza material, principalmente uma riqueza teórica, a elaboração de uma visão própria de mundo não subordinada ou colonizada por patrimônios ideológicos alheios. A capacidade de decidir e definir a identidade da própria subjetividade conforme uma filosofia própria, em que não haja mais discrepância entre o plano material e a auto-representação, entre o fazer e o saber dele" ${ }^{\text {.53. }}$.

48. Q 16, 1860, 99.

49. Q 13, 1561, 51 .

50. Q 4, 472, 545 .

51. Q 4, 471, 545 .

52. Q 10, 1345, 554 .

53. R. Finelli, “Marx e Gramsci: o confronto de duas antropologias”, In: G. Petrônio e M. P. Musitelli (orgs.) Marxe Gramsci: memória e attualità, Roma, Editora Manifestolibri, 2001, p. 105.

58 Neomarxismo e neopragmatismo no século XXI 
Isto quer dizer que, sem perder de vista este horizonte teórico-político desenhado por Gramsci no seu tempo, cada grupo social subalterno, em seu lugar e circunstâncias, tem a insubstituível tarefa de elaborar seus horizontes teóricos e construir a sua hegemonia. Hoje, por exemplo, a reelaboração da filosofia da práxis não pode deixar de levar em consideração que vivemos na época da globalização dominada pelo 'império' norte-americano; que, no pensamento pós-moderno, além de aspectos corrosivos, antidemocráticos e antipopulares, há elementos que podem ser aproveitados no fortalecimento das lutas dos subalternos ${ }^{54}$; que o conceito de política se ampliou e se complexificou muito; que o trabalho passa por um processo de intelectualização sem precedentes na história da humanidade; que a hegemonia deve ser equacionada com a questão do poder e suas múltiplas manifestações; que as lutas sociais se modificaram e múltiplos atores se organizam como novos protagonistas na esfera da política; que o socialismo não pode ser dissociado da realização da democracia; que no Brasil e na América Latina não há como pensar a construção de um 'outro mundo possivel' sem enfrentar e superar as contradições do sistema capitalista.

\section{A “NOVIDADE” DO NEOPRAGMATISMO DE R. RORTY}

Se a filosofia da práxis, para além de alguns pontos de aproximação, apresenta profundas divergências teóricas e contrapostos projetos de sociedade em relação ao pragmatismo clássico norte-americano, a distância se torna ainda mais nítida quando se examina o neopragmatismo desenhado por R. Rorty, herdeiro desta linha de pensamento.

Este representa, de fato, o pragmatismo norte-americano na versão pós-moderna mais sofisticada. Seus escritos procuram combinar o pensamento antimetafísico (antiessencialista e anti-representacionista) com um remodelado liberalismo "solidário" e um "vocabulário" inspirado na filosofia da linguagem.

Em Ensaios sobre Heidegger e outros; escritos filosóficos II ${ }^{55}$, o próprio Rorty explicita abertamente que o seu projeto filosófico visa interligar os pragmatistas, particularmente J. Dewey, a Nietzsche e Heidegger e aos filósofos analíticos norte-americanos (Quine, Davidson, Putnam).

54. Giovanni Semeraro, "Linhas de uma filosofia política da educação brasileira", Revista Movimento, no 10, 2004, p. 35-49.

55. R. Rorty, Ensaios sobre Heidegger e outros; escritos filosóficos II, Rio de Janeiro, Editora Relume-Dumará, 1999a, p. 14-15.

Marxismo e ciências humanas

cadernos cemarx, n03-2006 59 
Mas, embora mencione constantemente Dewey, na verdade Rorty está sintonizado com a filosofia da vida de Nietzsche e a crítica à "tradição ontoteológica" de Heidegger, ao mesmo tempo em que retira suas inspirações mais atuais de Donald Davidson, "um filósofo cuja obra parece-me ser a melhor declaração corrente de uma posição pragmatista"56. De fato, se por um lado, Rorty declara em diversas ocasiões que "a minha admiração por Dewey é quase ilimitada" 57 e que "o liberalismo naturalista e anti-ideológico deweano é a mais válida tradição da vida intelectual americana"; por outro lado, está convencido de que "o pragmatismo deveria desenvolver o lado holístico e sincrético para poder construir um invólucro melhor para o liberalismo"s8.

Pelo uso que faz dos seus referenciais teóricos e pelas suas próprias declarações, ficam evidentes as posições políticas que Rorty assume em defesa da "utopia liberal"59 e do modelo norte-americano de sociedade. Um liberalismo que, na esteira das reformadoras teorias de J. Rawls $^{60}$, Rorty espera ver renascer na América de hoje, já que "patriotismo, economia solidária, anticomunismo e pragmatismo de Dewey andavam juntos, fácil e naturalmente"61. Assim, não há escrito de Rorty onde não apareça, inabalável e indiscutível, metafisicamente presente como "mão invisível", a "crença" de que "sem [...] as instituições da sociedade burguesa liberal os homens teriam mais dificuldade para encontrar a própria salvação pessoal"².

Imbuído dessa "missão", Rorty, "anticomunista militante" de esquerda ${ }^{63}$, defende um "liberalismo democrático", uma "social-democracia reformista" que leve a purificarse do egoísmo e dos excessos da concorrência para tornar-se sensível ao sofrimento humano $0^{64}$ e impedir a crueldade ${ }^{65}$. Para tanto, sonha com um mundo onde as classes possam trabalhar "cooperativamente" ${ }^{\text {" }}$. Invoca as políticas reformistas de "Dewey e

56. Idem, ibidem, p. 26.

57. R. Rorty, Para realizar a América. O pensamento de esquerda no século XX na América, Rio de Janeiro, Editora DP\&A, 1999 b, p. 14.

58. R. Rorty, Objetivismo, relativismo e verdade; escritos filosóficos I, Rio de Janeiro, Editora Relume-Dumará, 1997, p. 93.

59. R. Rorty, La filosofia dopo la filosofia-contingenza, ironia e solidarietà, Roma, Editora Laterza, 2001, p. 218.

60. R. Rorty, Objetivismo, relativismo e verdade, cit., p. 23955.

61. R. Rorty, Para realizar a América, cit., p. 98.

62. R. Rorty, La filosofia dopo la filosofia, cit., p. 103.

63. R. Rorty, Para realizar a América, cit., p. 94.

64. R. Rorty, Ensaios sobre Heidegger e outros, cit., p. 67.

65. R. Rorty., La filosofia dopo la filosofia, cit., p. 82.

6६. Idem, ibidem, p. 89.

60 Neomarxismo e neopragmatismo no século XXI 
Hook, que lutaram com grande sucesso contra as tentações que o marxismo apresentou aos intelectuais americanos nos anos 30"67. Substitui a retórica dos direitos universais com as tradições genuínas do "nosso mundo" norte-americano ${ }^{68}$. Contrapõe o conceito de "societas" (sociedade que partilha valores específicos de um preciso grupo social) ao conceito de "universitas" (associação universal dos seres humanos que se reconhecem na mesma natureza humana $)^{69}$. Está convencido de que não se pode pensar a realização da democracia desvinculada do capitalismo: "Democracia participativa e fim do capitalismo são ideais que ninguém é capaz de imaginar sendo realizados"70. Para o que chama de "esquerda", indica que "deve voltar-se ao trabalho de reforma gradual dentro do quadro de uma economia de mercado" "71, de uma democracia já organizada, onde "nenhuma 'crítica radical' é requerida, sendo necessário apenas atenção para o detalhe", e onde "o filósofo [...] é alguém que provoca o confronto entre os bons e os maus aspectos dessa sociedade"72. Sem nunca pôr em dúvida a sacralidade do capitalismo, afirma que: "Deveríamos repudiar a insinuação dos marxistas de que só aqueles que estão convencidos de que o capitalismo deve ser superado podem ser tidos como de esquerda..." o capitalismo global a serviço da democracia [...] uma vez que hoje ‘socialismo' não significa outra coisa se não 'capitalismo domesticado'"'74.

Portanto, em contradição com as idéias de diferença, de democracia e de "conversação" aberta de que sua filosofia se diz portadora, Rorty toma partido indiscutível a favor do liberalismo, faz apologia dos seus heróis, valoriza autores de seu interesse e desqualifica outros que não têm "utilidade" para o seu discurso ${ }^{75}$, indica com precisão as leituras que servem para uma boa formação e outras que devem ser abandonadas ${ }^{76}$, ergue barreiras contra o marxismo, porque "para nós americanos é importante não

67. R. Rorty, Objetivismo, relativismo e verdade, cit., p. 107-108.

68. R. Rorty., Para realizar a América, cit., p. 84.

69. R. Rorty, La filosofia dopo la filosofia, cit., p. 75.

70. R. Rorty, Para realizar a América, cit., p. 139.

71. Idem, ibidem, p. 141.

72. R. Rorty, Ensaios sobre Heidegger e outros, cit., p. 39.

73. R. Rorty, Para realizar a América, cit., p. 76.

74. R. Rorty e G. Vattimo, Il futuro della religione; solidarietà, carità, ironia. Edição S. Zabala, Milano, Editora Garzanti, 2005, p. 82.

75. R. Rorty, La filosofia dopo la filosofia, cit, p. 100.

76. R. Rorty, Para realizar a América, cit., p. 93.

Marxismo e ciências humanas

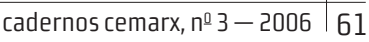


permitir que o marxismo influencie a história que contamos sobre nossa própria esquerda"77, uma vez que "nós americanos não precisamos de Marx para nos mostrar a necessidade de redistribuição..." ${ }^{.78}$. Assim, a aparente liberalidade do seu pensamento e a modéstia de objetivos que a sua filosofia se propõe mal escondem a intenção clara de "criar" um modo de pensar mais útil e prático para "refundar" mais eficazmente o liberalismo, modelo inigualável para o mundo, porque livre, sem amarras, sem princípios nem finalidade, cuja missão é "prevenir a miserabilização do proletariado país por país, no espírito pragmático e experimental que Dewey recomendou"79, e se manter armado, já que "A Guerra Fria [foi] travada [...] para salvar o mundo de um grande perigo" 80 .

Mas há outros aspectos que chamam a atenção quando nos adentramos na filosofia "solidária" e pós-moderna de Rorty. No mundo da sua encantadora literatura desaparece o "interesse" pelo contexto histórico dentro do qual deve-se entender os fatos, a linguagem, os valores. Em seus escritos não há sinal da divisão social do trabalho e sua exploração, dos processos históricos, das forças sociais, políticas e econômicas que formam mentalidades e amoldam comportamentos, que levam alguns povos a subjugar outros, que fazem acumular riquezas e concentrar poder no império norte-americano. No lugar de questões pouco pragmáticas como estas, que até suscitam sentimentos de indignação e piedade, Rorty concentra seus esforços sobre o esgotamento da filosofia ocidental tradicional e suas teorias "inúteis" para o nosso tempo.

Partindo da idéia de que estamos em época pós-metafísica e pós-filosófica, Rorty acredita ter havido um deslocamento da subjetividade/identidade fundada sobre a "consciência", para uma concepção que valoriza a completa naturalização das relações entre os homens e o meio. Nesta visão, organismo e ambiente, interno e externo, são considerados holisticamente relacionados única e exclusivamente por causação. $O$ modelo naturalista, de fato, dispensa a noção de consciência, de sujeito e de processos históricos. Ao abandonar a "metalinguagem" e a introspecção, e ao adotar a observação, o ponto de vista da terceira pessoa analisando expressões lingüísticas, crenças e desejos, Rorty pensa que é possível ser "ontologicamente neutro", "para além do bem

77. Idem, ibidem, p. 76.

78. Idem, ibidem, p. 84.

79. Idem, ibidem, p. 77.

80. Idem, ibidem, p. 95.

62 Neomarxismo e neopragmatismo no século XXI 
e do mal", pelo fato de limitar-se apenas a descrever, sem ideologia, o mundo com seus vários vocabulários, sem privilegiar nenhuma linguagem em particular. Na esteira de Nietzsche, portanto, a maior preocupação de Rorty é dissolver a filosofia do sujeito, da consciência, da razão, da verdade, da universalidade, substituindo-a pelo naturalismo, o holismo, a linguagem, a utilidade, a contingência.

Por isso, em conformidade com a "virada lingüística", a filosofia, nas mãos de Rorty, sofre também "a virada da teoria à narratividade" ${ }^{1}$. Neste sentido, o que nos restaria, agora, é aprender a nos "recriar" pela linguagem, a nos reescrever incessantemente por meio de novos vocabulários. O mundo pragmático, natural e palpável de Rorty nos orienta assim a "utilizar" impoliticamente termos e novas metáforas, sem se importar com o contexto histórico e sociopolítico. Rorty acredita, de fato, que:

"[...] a única coisa que podemos fazer para ampliar o raio dos nossos conhecimentos [...] consiste em ler livros, pois os irônicos passam mais tempo em colocar ordem entre os livros do que entre as pessoas concretas, reais. Eles temem que conhecendo apenas os habitantes do próprio bairro podem acabar presas do vocabulário no qual foram educados e, portanto, procuram conhecer pessoas estranhas (Alcebíades, Julien Sorel), famílias estranhas (os Karamazov, os Causabons) e estranhas comunidades (os Cavalheiros teutônicos, os Nuer, os mandarins da época Sung)" 12 .

Ao se dedicar aos romances e afastar seus olhos das contradições sócio-políticoeconômicas existentes no mundo, o neopragmatismo de Rorty quer nos fazer crer que hoje não há mais problemas filosóficos "fundamentais" a serem resolvidos e que a filosofia não passa de uma "crítica literária"83, de uma "prática discursiva" entre outras que caracterizam a nossa convivência. Por isso, a filosofia deve abandonar sua pretensão de elaborar visões globais de mundo, de fundamentar o conhecimento e de dar sustentação a práticas éticas e políticas, para transformar-se em uma espécie de narrativa, sem nenhuma tentativa de chegar a uma teoria abrangente ou a um projeto de sociedade. Pois, agora, trata-se não de elaborar conceitos, mas de transitar entre vocabulários; não de construir uma epistemologia, mas de dedicar-se aos jogos de linguagem; não de argumentar, mas de justificar para "audiências"; não de auscultar a realidade, mas de "conversar" sobre ela. Qualquer coisa a mais do que isso levaria

81. R. Rorty, La filosofia dopo la filosofia, cit., p. 5.

82. Idem, ibidem, p. 98.

83. Idem, ibidem, p. 99.

Marxismo e ciências humanas

cadernos cemarx, n03-2006 63 
aos perigos da "sobre-filosoficação". Convencido disso, Rorty pode declarar que "Se considerássemos a história humana como história de metáforas sucessivas, para nós o poeta, no sentido geral do artífice de novas palavras, criador de novas linguagens, seria a vanguarda da espécie" ${ }^{4}$. Este "gênio", sendo o único que "sabe contar a história", tem sua superioridade assegurada em relação "ao resto da raça humana" ${ }^{\text {. }}$. Em conformidade com o elitismo de Nietzsche e Heidegger, Rorty também acredita que as mudanças no mundo acontecem pelas "revoluções conceituais" ${ }^{86}$, pela introdução de "novas metáforas", pelas idiossincrasias dos grandes pensadores ${ }^{87}$, sem relacionálas às lutas concretas de grupos sociopolíticos, a complexas disputas de contrapostos projetos de sociedade, menos ainda suspeitar que muitas idéias e "metáforas" podem se originar nas ações e nas reflexões de seres humanos comuns.

Com esta reinterpretação da filosofia, o que nos restaria - melhor, aos poetas e pensadores - são as narrativas e os vocabulários, pelos quais "as coisas se tornam mais prontamente manipuláveis", sem esperar alcançar algo, uma vez que "não há nada a ser conhecido sobre coisa alguma a não ser suas relações com outras coisas"88. A meta da investigação e da ciência, de fato, não é a verdade, mas a utilidade. Darwinianamente, é a capacidade cada vez maior de formar os instrumentos necessários para a espécie humana sobreviver. No entendimento pragmatista da investigação, "a linguagem é um conjunto de instrumentos", é um conjunto de "sinais e ruídos que os organismos usam como ferramenta para conseguir o que eles querem" 89 . Sendo assim, a linguagem não deve ser vista como um "quebra-cabeça" para descobrir algum desenho escondido do mundo ou um significado global da existência. De fato, uma vez que a filosofia tradicional faliu com a sua imagem "da mente como sendo um grande espelho" capaz, com seus "métodos puros", de chegar ao conhecimento entendido como "representação" precisa do mundo e capaz de elaborar "uma teoria geral da representação"

84. Idem, ibidem, p. 30.

85. Idem, ibidem, p. 39.

86. R. Rorty, Ensaios sobre Heidegger e outros, cit., p. 29.

87. Idem, ibidem, p. 29.

88. R. Rorty, Pragmatismo. Filosofia da criação e da mudança, Edição C. Magro e A. M. Pereira, Belo Horizonte, Ed. UFMG, 2000, p. 67 e segs.

89. R. Rorty, Ensaios sobre Heidegger e outros, cit, p.17.

90. R. Rorty, Philosophy and mirror of nature, Princeton, Ed. Princeton University Press, 1979, p. 6-12.

64 Neomarxismo e neopragmatismo no século XXI 
que nós temos agora é só um "vocabulário contingente" utilizado por uma "comunidade restrita" 91 .

Se vivemos em uma seqüência aleatória de acidentes e palavras, não podemos ter a pretensão de compreender e representar a realidade. Então, mais do que uma verdade, é preciso justificar "crenças" para uma audiência com mais facilidade que outras, pois só há vários objetivos locais, práticos, precisos, nenhum objetivo geral porque não há nenhuma justificação última, como não há nenhum centro considerado "consciência" porque não há nenhum "ponto arquimediano"92.

\section{"Praticamente", em Que Consiste o (neo)pragmatismo?}

A centralidade do "uso de vocabulários contingentes", da "conversa" e da "narrativa" na filosofia de Rorty são tão fortes que chega a operar uma separação entre o mundo da fala e as práticas de vida. Assim, contraditoriamente com seu discurso, mas coerente com o liberalismo que defende, Rorty acaba separando o pensamento do agir político. Refunda, assim, o dualismo que pensava ter superado, a tal ponto de não se importar com o comportamento e as escolhas concretas do filósofo, uma vez que o que vale é o que este pensa e escreve ${ }^{93}$. Em um dos exemplos mais ilustrativos dessa atitude, Rorty chega a instruir M. Foucault sobre como deveria ser um verdadeiro filósofo: "Eu estou com vocês enquanto um companheiro cidadão, mas, enquanto filósofo, estou retirado em mim mesmo, perseguindo projetos de auto-invenção que não são do seu interesse. Eu não estou interessado em oferecer fundamentações filosóficas que legitimem o fato de eu estar do seu lado, pois meu projeto filosófico é um projeto privado que não provê nem motivos nem justificações para minhas ações políticas". ${ }^{94}$

Como Nietzsche, acreditando que a realidade é "um exército móvel de metáforas", e que "não há fatos, mas só interpretações", o que importa para Rorty é a fabulação e a ironia, não a transformação do mundo.

Contrariamente à filosofia da práxis, portanto, não é a realidade dos grupos humanos concretos, a premência dos seus problemas, a disputa de projetos alternativos

91. Idem, ibidem, p. 365.

92. R. Rorty, Pragmatismo. Filosofia da criação e da mudança, cit., p. 37-44.

93. Idem, ibidem, p. 171.

94. R. Rorty, Ensaios sobre Heidegger e outros, cit., p. 263.

Marxismo e ciências humanas

cadernos cemarx, $n^{0}-3-2006 \quad 65$ 
de sociedade, mas, hollywoodianamente, as narrativas, os novos vocabulários, as boas intenções de "grandes" autores depositados em livros e seus jogos de linguagem que alimentariam a solidariedade e a criação de novos espaços de convivência. Justamente, Susan Haack ${ }^{95}$ observa que em Rorty, as terapias de grupo e as práticas discursivas assumem o lugar dos problemas reais a serem resolvidos. E Habermas, em sua crítica a Rorty, observa que "Quando o pensamento filosófico [...] é desvinculado do dever de resolver problemas, e o seu fundamento é transferido para a crítica literária, é-lhe subtraída não só a sua seriedade, mas também a sua produtividade e criatividade" 96 .

Rorty, de fato, acredita que o simples mudar do nosso modo de falar, mudaria "o que queremos fazer e que pensamos de ser"97. O novo demiurgo, portanto, é a linguagem, melhor, os "novos vocabulários". No lugar do Ser, de Deus, da Razão, da Historia, do Espírito, do Partido, são os fonemas, os "sinais e os ruídos" que chegam a "criar a pessoa humana [...] a fazer aparecer boa ou má, importante ou secundária, útil ou inútil qualquer coisa"98.

Neste sentido, a própria sedutora e risonha narrativa de Rorty não é apenas talento pessoal. É a expressão literária de um pensamento que traduz os valores que defende. Seu estilo desinibido, irônico, ousado, seguro, agradável, erudito, está intimamente sintonizado com o método de "bricolagem de discursos", com a liberdade de "construir textos com tramas múltiplas de narrativas provocadoras, contingentes com suas necessidades de cada momento"99, como o liberalismo quer.

Com esta "liberdade", Rorty se esmera em "utilizar" como acha melhor o pensamento de qualquer autor, tentando juntar em seus textos "metáforas" de Hegel e Marx com as de Kierkegaard, Nietzsche, Heidegger e Derrida; afirmações de Dewey e Rawls com proposições de Mill e Habermas ${ }^{100}$. Sem se importar com o conjunto da obra de um autor e o contexto histórico-político em que escreve, Rorty espera assim, pela via da narrativa e da linguagem, construir holisticamente um "belo mosaico"101. Neste sentido,

95. S. Haacks, “Quanto àquela frase “estudando com espírito literário...", in: P. R. Margutti Pinto (org.), Filosofia analítica, pragmatismo e ciência, Belo Horizonte, Ed. UFMG, 1998, pp. 40-70.

96. J. Habermas, O discurso filosófico da modernidade, Lisboa, Editora Dom Quixote, 1990, p. 198.

97. R Rorty, La filosofia dopo la filosofia, cit., p. 29.

98. Idem, ibidem, p. 14.

99. R. Rorty, Pragmatismo. Filosofia da criação e da mudança, cit., p. 11 e segs.

100. R. Rorty, La filosofia dopo la filosofia, cit., p.2 e segs.

101. Idem, ibidem, p. 99.

6६ Neomarxismo e neopragmatismo no século XXI 
para fundamentar o neopragmatismo, não apenas Nietzsche e Heidegger nos revelam que as categorias da razão "são meios para o ajuste do mundo a certos fins utilitários", mas também que "só nos tornamos pragmatistas porque Platão e Aristóteles já nos deram um avaliação técnica, instrumental, de para que serve o pensamento"102. Com a mesma liberdade pragmática, Rorty chega a afirmar que as Teses contra Feuerbach de Marx formam uma plataforma do pragmatismo ${ }^{103}$ e que o método dialético de Hegel é "simplesmente uma técnica literária", que "não tem por objetivo reatar o sujeito com o objeto", que "abandona a idéia de chegar à verdade", que "inaugurou uma tradição da filosofia irônica que continua em Nietzsche, Heidegger e Derrida"104. Por estas e tantas outras afirmações, percebe-se melhor por que Rorty trava suas lutas em defesa da "contingência": porque só esta, afinal, nos habilita na "capacidade de manipular entes para satisfazermos nossos próprios desejos" 105 . Pela mesma razão, foi observado que quando se procura "desfundamentar" a idéia de natureza humana e de "substância", se objetiva derrubar a idéia de igualdade ${ }^{106}$.

Mas esta habilidade manipulatória nos confirma ainda mais que de "contingente, irônico e solidário", Rorty possui apenas a literatura, porque seus fundamentos a priori e a "crença" em um projeto preciso de sociedade aparecem perfeitamente sólidos e inabaláveis. Pois, quanto mais combate os fundamentos dos ...outros mais 'fundamentalista' torna-se o seu discurso. O livre, neutro, antimetafísico, contingente e criativo neopragmatismo de Rorty, de fato, não consegue se livrar do seu inquestionável "fundamento" da "American way of life", do seu intocável "ponto arquimediano": o pressuposto "liberal" da existência do indivíduo natural, autônomo, destituído de consciência e interioridade, mas dotado de "crenças" e "desejos", capaz de interação com o universo, mas avesso a buscar visões de mundo que o exponham a se tornar um "ser social" e politicamente organizado. Não há surpresa nisso se considerarmos que em Rorty, como em seu mestre Nietzsche, há uma visão naturalista entre os seres humanos e o resto do universo:

"Pois, afinal, a autêntica novidade pode muito bem acontecer em um mundo de

102. R. Rorty, Ensaios sobre Heidegger e outros, cit., p. 48. 103. Idem, ibidem, p. 41.

104. R. Rorty, La filosofia dopo la filosofia, cit., p. 96 e segs. 105. R. Rorty., Ensaios sobre Heidegger e outros, cit., p. 61. 106. Domenico Losurdo, Nietzsche, il ribelle aristocratico; biografia intellettuale e bilancio critico, Torino, Editora Bollati Boringhieri, 2002, p. 710.

Marxismo e ciências humanas cadernos cemarx, n03-2006 67 
forças cegas, contingentes, mecânicas. [...] assim, pelo que nós sabemos, ou que nos importa, o uso metafórico da palavra ousia da parte de Aristóteles, de agape da parte de São Paulo, e de gravitas da parte de Newton, foi o resultado da descarga produzida por um raio cósmico na estrutura de alguns neurônios determinantes do cérebro deles. Ou, como é mais plausível, foi o fruto de algum episódio peculiar da infância deles, de uma idéia fixa produzida por algum trauma pessoal" ${ }^{107 .}$

Esta naturalização serve para Rorty justificar as distâncias que quer tomar das tendenciosas posições político-ideológicas que poderiam pôr em questão a "inocência" do liberalismo com o qual sonha, cuja "substância" permanece dualista porque prega a ironia privada e a solidariedade pública, invoca a piedade diante das crueldades humanas, mas se recusa a descobrir as causas. E não se pode pensar que estas contradições lhe escapam, pois Rorty é um intelectual muito informado para não saber que certas filosofias por ele desqualificadas ameaçam concretamente desmascarar a perversidade do sistema em que vivemos, as desigualdades por ele produzidas, as gigantescas transferências de recursos drenadas dos países pobres para os centros de poder, a militarização que isso comporta, o terrorismo ideológico e financeiro, o aprofundamento da divisão de classe, o fosso que está dividindo tragicamente a humanidade em fronteiras que segregam multidões empobrecidas de grupos humanos encastelados em altos padrões de consumo e de cultura.

Longe desta realidade "irrelevante", a filosofia de Rorty procura seu brilho na esgrima que trava com o pensamento tradicional europeu, na desconstrução de um passado cuja visão "ocular" e racionalidade impediriam a liberdade da sua própria afirmação, da sua "autocriatividade" e da "redescrição" de si próprio. Para ele, de fato, as questões mais importantes se concentram nos dualismos entre a tradição metafísica e a linguagem atual, a modernidade e a pós-modernidade, a filosofia continental e norte-americana. Não lhe importa verificar se os dualismos, antes do que na esfera da metafísica e do discurso, não nascem, acima de tudo, das relações que se estabelecem entre dominadores e subjugados, entre quem estabelece "valores" conforme seus interesses e os que são empobrecidos. Quando se recusa olhar para esta realidade, de pouco serve evadir-se no mundo das palavras. Agindo assim, se contribui para a manutenção e a "fundamentação" de outros dualismos igualmente perversos: a separação da filosofia da política, o público do privado, a narrativa

68 Neomarxismo e neopragmatismo no século XXI 
das estruturas econômicas, a "societas" de protegidos separada da "universitas" da maioria entregue à "caridade". Por isso, à filosofia de Rorty não interessa a realidade na sua complexa concretude, mas apenas o "jogo de palavras", o construcionismo permanente de acordo com os interesses de um grupo social particular, assumidamente "etnocêntrico"108, que tudo faz para defender os seus valores que continuam "essencialmente" ocidentais. Ao recusar a análise das contradições e dos processos históricos, a compreensão do mundo em que se debatem outros grupos sociais e diferentes projetos de sociedade, o neopragmatismo de Rorty acaba comprometendo também seus próprios esforços de valorizar o particular e o contingente, porque os volatiliza e os exclui de uma relação maior.

Contrariamente ao que Rorty gosta de apresentar, totalidade, de fato, não significa necessariamente visão totalitária, exaustiva, fechada, única, definitiva, mas, na longa tradição dialética, deve ser entendida como uma compreensão, a mais ampla possível, histórica e superável, que conseguimos alcançar da complexa e contraditória realidade na qual nos movemos interativa e conflitivamente, em busca de conexões entre partes e todo, micro e macro, para melhor termos condições de transformá-la individual e conjuntamente.

Ao descartar esta leitura dialética - que o tão mencionado Hegel define como "ciência das contradições e das conexões universais" -, o neopragmatismo de Rorty, no lugar de construir o concreto ("rica totalidade de múltiplas determinações"), acaba se tornando redutivo, imediatista e abstrato. Sem uma relação maior, até o uso instrumental e operacional dos seus vocabulários fica inviabilizado e a "metafísica" da "utilidade" e da "contingência" defendida por Rorty torna-se pobre e sem saídas. Transforma-se em uma ilusão pior que a criada por Platão, por ele incansavelmente combatido. A aposta na contingência, nos vocabulários, na ironia, mais do que uma ruptura com a filosofia tradicional, na verdade, operam apenas uma inversão, "do Ser para os entes", deixando a lógica subjacente substancialmente igual.

A metafísica, de fato, não se combate jogando todas as cartas sobre a aparência e os rodeios das palavras, como haviam já feito os sofistas. K. Otto Apel ${ }^{109}$, justamente, tem observado que quando alguém troca alegremente a "episteme" pela "doxa", a "verdade" pelo "útil", acaba renunciando à sua capacidade racional e à visão de conjunto. Quem

108. R. Rorty, La filosofia dopo la filosofia, cit., p. 227.

109. K. O. Apel, Estudos de moral moderna, Petrópolis, Editora Vozes, 1994.

Marxismo e ciências humanas

cadernos cemarx, n03-2006 69 
abraça esta inversão, como Rorty, se recusa a perceber que as armadilhas do poder existem tanto na metafísica tradicional como também na pressuposição de que tudo se desintegra e volatiliza no ácido corrosivo do relativismo. Não se dá conta de que o "poder" do seu neopragmatismo, tão sutil como a "metafísica" das suas "crenças" sem aparente teoria e visão de mundo, afinal de conta, acaba se colocando a serviço de um liberalismo pós-modernizado e de um capitalismo virtual que combate a política, a formação de subjetividades, do público, dos direitos universais, de outros possíveis projetos de sociedade, porque se recusa a admitir a realidade que produz: o trágico dualismo na humanidade e a destruição do planeta.

70 Neomarxismo e neopragmatismo no século XXI 